THE SUB-OCEANIC VALLEY OF THE RIVER CONGO.

SIR, - I have just completed the details of this magnificent submerged river-channel by means of the soundings on the Admiralty chart No. 604. Fortunately they are sufficiently numerous at this part of the African coast to enable me to do so with great accuracy. That the Congo valley is continued under the Atlantic to a great depth has been known for some years, and accompanying the paper by Mr. Edward Stallibrass on "Deep-sea Soundings in connection with Submarine Telegraphy," "there is a plan of this sub-oceanic valley from the mouth of the Congn down to the 1,000-fathom contour, which very closely corresponds with that drawn by myself. The scale of Mr. Stallibrass' map is about balf that of the Admiralty chart, or about 25 miles to the inch : the details deserve publication on the full scale. The length of the submerged valley is about 120 miles, and, like those of the West of Europe, it opens out on the abyssal floor at a depth of 1,200 fathoms. The valley is remarkably straight for a distance of about 100 miles, and nearly coincides with the 6th parallel of South latitude, but at this point bends slightly northwards. It is generally narrow, and bounded by walls, in some places precipitous, descending to depths of $2,000-4,000$ feet within very short horizontal spaces, and the average fall of the channel is 60 feet per mile. It is unnecessary to point out the significance of the presence of this great submerged river valley as far south as $6^{\circ}$ beyond the Equator. It proves beyond question that the western margin of Africa has shared in the great upheaval and subsequent depression by several thousand feet of that of Western Europe and the British Isles, and, let me add, represents on the eastern side of the Atlantic the uprise and depression of the Antillean continent so ably elucidated by Professor Spencer. I hope to treat this subject more fully in a paper to be read before the Victoria Institute this session.

Edward HuLr.

January 15, 1900.

\title{
OEITUARY. \\ JOHN RUSKIN, M.A., LL.D., D.C.L., F.G.S.
}

Bord February, 1819.

DibD JANUary 20, 1900.

The great Art-writer and Critic of the century, John Ruskin, passed away peacefully on the afternoon of Saturday, 20th January, his life's work accomplished long since.

Few men have had greater influence on modern thought in matters pertaining to art, pictures, sculpture, and architecture than John Ruskin; he was always an idealist and romantically enthusiastic in his notions, and wholly unworldly, yet no one believed more strongly than he did in his ability to regenerate the world and reform its abuses. His kindness of heart was extreme, and his sympathies were universal. $\mathrm{He}_{e}$ has been, as such a man naturally would be, severely criticized for his published views on 'Political Economy,'

1 Journ. Telegraphic Engineers, vol. xvi (1888), p. 479. 
and his fierce comments on those manufacturers and merchants who pile up riches by the employment of labour. Doubtless Ruskin forgot for the moment that his own splendid abilities mainly owed the opportunity for their development and sustained energy through life to the accumulated fortune of his father, a partner in the firm of Ruskin, Telford, \& Domecq, London.

His success as an art-critic and writer gave him unbounded belief in his power to carry out any matter upon which he had set his heart. Thus, at one time (resenting the intervention of publishers) he determined to print, illustrate, and publish his own works. At another time he started a business as a tea-dealer in order to show that trade might be conducted in an honourable and honest manner. He encouraged the undergraduates at Oxford to dig and repair the roads; and he bimself undertook to keep the streets clean betwoen the British Museum and St. Giles', engaging a staff of helpers and setting them an example of their duties.

Everyone who loves Ruskin is, of course, well acquainted with his numerous works-his "Modern Painters," "Stones of Venice," "Seven Lamps of Architecture," "Lectures on Architecture and Painting," "Fors Clavigera," "Ethics of the Dust," "Sesame and Lilies," and some thirty other works, essays and lectures. But how many are aware that he had a strong attachment to geology and mineralogy !

When taken as a boy to Wales by his parents he enjoyed his first sight of really bold scenery ; he ascended Snowdon and Cader Idris, and, to his intense delight, found for the first time in his life a real mineral. Ruskin believed if he had been allowed to remain there in charge of the good Welsh guide and his wife they would have made a man of him, and also "probably the first geologist of my time in Europe." Although this youthful dream was never realized, and he devoted his after years to art and architecture, his crossings and recrossings of the Alps in his frequent pilgrimages to his beloved Italy made a powerful impression upon his imagination, as may be seen by his notes and sketches published in the Geologioar Magazine for 1865 , whilst his subsequent papers on Banded and Brecciated Agates, 1867-1870, op. cit., may still be read with intense pleasure for their wonderful word-painting; these, too, being all illustrated by Ruskin's own hand. His "Deucalion" on Geology is also most attractive.

Only a few years since be was deeply engrossed in arranging a case of specimens in the Mineralogical Gallery of the British Museum of Natural History, Crom well Road, to illustrate the structure of Agates, accompanied by a printed description by himself. To this collection he also presented the great South African uncut natural gem, which he named the "Colenso Diamond" after the late Bishop Colenso. The Ruskin Museum, founded by him at Meersbrook Hall, near Sheffield, is a treasure-house of Art, in which minerals also find a place. Of Ruskin's many acts of noble generosity to the world the public Press is now everywhere speaking in most just and appreciative praise; the innumerable kindnesses which he secretly performed will never be known, but they will serve to keep his 
memory green in the hearts of a large circle, to whom, although occupying quite humble positions, he had endeared himself for all time by calling them his friends.

Titles of Prop. Ruskin's Papers printed in the Grological Magazini.

1. "Notes on the Shape and Structure of some parts of the Alps, with reference to. Denudation." Vol. II (1865), pp. 49-54 and 193-196, Pl. VI and Woodcuts.

2. "On Banded and Brecciated Concretions." Vol. IV (1867), pp. 337-339, Pl. XY.

3. "On Brecciated Formations." Vol. IV (1867), pp. 481, 482, Pl. XX.

4. "On Brecciated Concretions." Vol. V (1868), pp. 12-18, P1. III and Woodcuts; pp. 159-161, Pl. X; and pp. 208-213, Pl. XIII and Woodeuts.

5. "On Brecciated Concretions." Tol. VI (1869), pp. 529-534, P1. XIX and Woodeuts.

6. "On Banded and Brecciated Concretions." Vol. VII (1870), pp. 10-14, Pl. II and Woodcuts.

MISCEIIA NTEOUS.

Presentation of a Testimonial to the Rev. Professor Wrutshine, M.A., D.Sc., F.L.S., F.G.S., ETc., Honorary Secretary of the Ray and Palæontographical Societies.-A well-attended meeting of the members of the Palæontographical and Ray Societies was held at the Geological Society's Apartments, Burlington House, on Tuesday, December 19 ; the Rt. Hon. Sir John Lubbock, Bart., ${ }^{1}$ P.C., M.P., D.C.L., LL.D., F.R.S., President of the Ray Society, in the chair, supported by Dr. Henry Woodward, F.R.S., F.G.S., President of the Palæontographical Society. The object of the joint meeting was to present to the Rev. Prof. Wiltshire, the Hon. Secretary of both the above-named Societies, his portrait in oils, an illuminated address, and a cheque for $\mathscr{L} 138$ - the balance of the sum subscribed after defraying expenses-in recognition of the services rendered by him to these Societies and to Palæontology and Zoology during a period of more than thirty years. The portrait was executed by Miss. Atkinson, the illuminated address by Miss G. M. Woodward. Among those present were-The Right Rev. Bishop Mitchinson, Master of Pembroke, Oxford; Professor T. McKenny Hughes, F.R.S., and Professor W. J. Lewis, of Cambridge; the Rev. R. A. Bullen, the Rev. G. F. Whidborne, V.P. Pal. Soc., the Rev. H. H. Winwood, Dr. W. T. Blanford, F.R.S., Mr. John Hopkinson, Professor T. Rupert Jones, F.R.S., Sir Owen Roberts, Dr. D. H. Scott, F.R.S., Mr. F. W. Rudler, F.G.S., and Mr. A. Strahan; many ladies were also present. The presentation address was delivered by Sir John Lubbock, and the Rev. Professor Wiltshire responded. Speeches were also made by Dr. Woodward, Professor T. McKenny Hughes, Rev. G. F. Whidborne, and the Rev. H. H. Winwood; 132 subscribers took part in the testimonial.

Corrigenda.-In Mr. F. Chapman's paper on Patellina-limestone, which appeared in our last issue, the following corrections should be made: pp. 11, 12, and 17, for Patellina Egyptiensis read Patellina Egyptiensis; pp. 13 and 17, for Polytrema papyracea read Polytrema papyraceum. - Also on p. 40, line 20 from foot, for "Applied Geology," read "Applied Geography."

\footnotetext{
1 Now "Lord Avebury."
} 